et souvent G. de Sauza n'hésite pas à recourir à une très salutaire paraphrase. Peut-être ce souci le conduit-il parfois à un excès de zèle se traduisant par la présence de notes dont l'utilité n' apparaît pas clairement : par exemple, et sauf à désespérer de la perspicacité du lecteur, était-il nécessaire de préciser en note, pour le début du vers 12 du sonnet 10 (« Ha, ne laissez, ô Dieux...»), que "le sujet lyrique fait appel aux dieux païens, non au Dieu chrétien » (p. 46) ? Inversement, on apprécie particulièrement, par exemple et parmi d'autres, la très convaincante note 213 de la page 91 qui, après avoir fait le point sur les difficultés d'interprétation posées par le vers 14 du sonnet XXXIV («D’une dolente, et funebre Lidie »), identifie une source qui éclaire de façon décisive, à nos yeux, le passage. Signalons enfin une petite étourderie à corriger dans cette annotation : dans la note 416 p. 135, "Comprendre : parce qu'elle pensait ", corriger « elle» en « il».

Le texte des Erreurs amoureuses est suivi d'un glossaire référencé s'ouvrant sur une utile note signalant les formes verbales posant des difficultés d'identification et les substantifs dont le genre a changé de sens.

Cette édition est donc réalisée avec grand soin et un souci constant de rendre le texte accessible au plus grand nombre. Elle satisfait tout autant l'étudiant que le spécialiste, et son prix accessible devrait permettre au second d'initier le premier à la poésie tyardienne dans le cadre de programmes universitaires.

DANIEL MARTIn, Université d'Aix-Marseille

\title{
Streete, Adrian.
}

\section{Protestantism and Drama in Early Modern England.}

New York: Cambridge University Press, 2009. Pp. x, 298. ISBN 978-0-52176017-1 (hardcover) \$95.

Adrian Streete's Protestantism and Drama in Early Modern England centres its attention on how early modern subjectivity, and representations thereof in the drama of the period, are conditioned by the Protestant theologies disseminated and debated in late sixteenth-century England. Streete's book is structurally bifurcated, treating in its first half the question of how the theological positions advanced by reformers like Luther and Calvin instantiated a fundamentally 
fraught subjectivity, torn between the ideal of the imitatio Christi on the one hand and profound anxieties about mankind's inherent degeneracy, incapacity for virtuous volition, and inability to access material signs of salvation or reprobation on the other. In the book's second section, Streete turns his attention to the period's drama, exploring how Reformed theological discourse conditioned contemporary theatrical representation, offering close readings of Christopher Marlowe's Doctor Faustus, William Shakespeare's Richard II, and Thomas Middleton's The Revenger's Tragedy.

Examining the theological, theoretical, and literary implications of a Christological representational system, Streete challenges the notion of religious pluralism dominating current criticism in the field and offers a corrective to readings of Protestant subjectivity that would either characterize it "as an irredeemably anticipatory moment in the relentless rise of the rational modern subject" (78) or position its Christological concerns in sharp contrast to a putatively secular form of subjectivity constructed through Renaissance self-fashioning. Streete's delineation of anxious early modern Protestant subjectivity is culled from a variety of religious discourses ranging from texts by à Kempis and Erasmus to those of Luther and Calvin, and Streete's premise is on its surest footing as he demonstrates the recapitulation of those theological positions in the poetry of religious thinkers like Fulke Greville and John Donne. Streete's careful attention to the paradoxical implications of Reformed theology also pays rich dividends in the second section of the book, where he turns his attention to the drama, particularly when he is interrogating these patterns in plays that test the limits of biblical exegesis or explicitly explore the intersections of theology and subjectivity. In Marlowe's Doctor Faustus, for example, Streete usefully challenges Faustus' being read by modern scholars as an exemplum of transcendent secular overreaching, an interpretation that seems more akin to the ethos of post-Enlightenment liberal humanism than to a subjectivity produced in relation to late Elizabethan Protestantism. Emphasizing not Faustus' metaphysical transcendence but rather the play's depiction of a tortured Calvinist subjectivity yearning for knowledge of reprobation or salvation and facing the direct consequences of a vexingly absent Christ, Streete persuasively argues that Faustus' demise ultimately foregrounds how a radically anti-Christian subjectivity is the potential consequence of Reformed Christology's typological logic. 
Due in part to the paucity of dramatic examples offered, Streete is less convincing when he attempts to illustrate the omnipresence of tortured Protestant subjectivity in less overtly religious plays. In order to apply his model to secular drama's concerns over the problems of signification and to the genre of revenge tragedy, Streete suggests that Protestant theology's predestinarian, eschatological, and iconoclastic aspects denied early modern subjects emotional or epistemological certitude, thus opening up a space for fantasy as a surrogate for grace, but this premise remains comparatively vague and underdeveloped. In his chapter devoted to the discussion of perception and fantasy, Streete offers an exemplary reading of Shakespeare's Othello to demonstrate his contention that the Christian fantasy of coming face to face with God "generates the dialectical axis of identification and repudiation upon which the Protestant subject is produced" (123), but he offers little evidence to support the generative aspect of this claim - that religious alienation is the fundamental root cause of the epistemological crisis that haunts the play. Moreover, early modern subjectivity in Streete's analysis at times seems disconcertingly monolithic, despite the author's acknowledging an overlap in the discourses of Protestant iconoclastic polemic and theatrical cross-dressing, for example. Whether the particulars of race or social status nuanced Reformed subjectivity, or whether early modern women faced specific challenges and obstacles in their desires to imitate Christ (Shakespeare's Isabella in Measure for Measure might offer a tantalizing example), this book never indicates. Rather than gaining momentum, Streete's point becomes progressively convoluted and diluted until the discussion threatens to overtax the delicate network of tenuous association. By the final chapter, some readers might be left wondering whether patterns of Protestant theology in the drama are more ambiguous and less ubiquitous than they formerly seemed. Nevertheless, the book's foremost concerns-that scholars of the period not mistake religious hegemony for plurality, the fundamentally Christological focus of Reformed theology, the ambiguous, fraught, and vexingly contradictory construction of early modern Protestant subjectivity, and the imbricative aspects of the period's religious, literary, and dramatic discourses-resonate, strongly advocating the need for more careful consideration and sustained examination of the complex intersections of early modern Protestantism, subjectivity, and representation. 